LISANUL ARAB 10 (1) (2021)
(Terakreditasi Sinta 4)
http://journal.unnes.ac.id/sju/index.ph/laa

\title{
PENGEMBANGAN BUKU PENUNJANG KETERAMPILAN MENULIS BAHASA ARAB BERBASIS STRATEGI RAFT (ROLE AUDIENCE FORMAT TOPIC) UNTUK SISWA KELAS VIII MTS DI KOTA SEMARANG
}

\author{
Syakirotun Ni’mah ${ }^{\bowtie}$, Zaim Elmubarok ${ }^{\bowtie}$, Zukhaira ${ }^{\bowtie}$
}

Jurusan Bahasa Asing, Fakultas Bahasa dan Seni, Universitas Negeri Semarang, Indonesia

\begin{tabular}{l}
\hline Info Artikel \\
\hline Sejarah Artikel: \\
Diterima Januari 2021 \\
Disetujui Maret 2021 \\
Dipublikasikan April \\
2021 \\
\hline Keywords: \\
Supporting Books; RAFT \\
Strategy (Role Audience \\
Format Topic); Arabic \\
Writing Skills.
\end{tabular}

\begin{abstract}
Abstrak
Penelitian ini dilatar belakangi oleh kesulitan siswa dalam mempelajari bahan ajar dianggap sebagai faktor utama kesulitan. Hal ini dikarenakan materi pada buku teks pelajaran terkesan kaku atau terikat pada materi pokok dalam kurikulum sehingga kurang mengembangkan kemampuan berpikir kreatif siswa. Oleh karena itu, peneliti mengembangkan sebuah buku penunjang keterampilan menulis bahasa Arab berbasis strategi RAFT (Role Audience Format Topic) untuk siswa kelas VIII MTs sebagai upaya menumbuhkan kemampuan berpikir kreatif siswa dalam keterampilan menulis bahasa Arab. Penelitian ini menggunakan jenis penelitian kualitatif dan kuantitatif dengan desain penelitian dan pengembangan (Research and Development). Tahapan penelitian yang dilalui dalam penelitian ini hanya sampai pada tahap lima dari sepuluh tahap, yaitu potensi dan masalah, pengumpulan data, desain produk, validasi desain, dan revisi desain. Hasil penelitian ini adalah sebagai berikut. Pertama, guru dan siswa menghendaki adanya pengembangan buku penunjang keterampilan menulis bahasa Arab berbasis strategi RAFT untuk siswa kelas VIII MTs. Kedua, purwarupa buku penunjang ini memuat kosakata, pedoman gramatika, contoh menulis dengan strategi RAFT, latihan menulis dengan strategi RAFT dan kata mutiara. Ketiga, Penilaian aspek kelayakan isi memperoleh nilai rata-rata 90,56, aspek kelayakan penyajian 90,95, aspek kelayakan bahasa 89,66, dan aspek kelayakan kegrafikan 89,77. Nilai rata-rata dari keseluruhan aspek kelayakan buku adalah 90,23 pada rentang 86-100 dan termasuk kategori 4 (sangat sesuai).
\end{abstract}

\begin{abstract}
This research is motivated by the difficulties of students in learning teaching materials are considered the main factor in these difficulties, because the material in the textbook seems stiff or tied to the main material in the curriculum so that it does not develop students creative thinking skills. Therefore, the researcher developed a book supporting Arabic writing skills based on the RAFT strategy (Role Audience Format Topic) for eighth grade students of MTs as an effort to foster students creative thinking skills in Arabic writing skills. This research uses qualitative and quantitative research with a research and development design (Research and Development). The research stages that were passed in this study only reached the fifth stage of the ten stages, namely potentials and problems, data collection, product design, design validation, and design revision. The results of this study are as follows. First, teachers and students want the development of books to support Arabic writing skills based on the RAFT strategy for grade VIII students of MTs. Second, this supporting book prototype contains vocabulary, grammar guidelines, examples of writing with RAFT strategy, writing exercises using RAFT strategy and pearls of wisdom. Third, the assessment of the content feasibility aspect obtained an average value of 90.56 , the feasibility aspect of presentation was 90.95 , the language feasibility aspect was 89.66 , and the graphic feasibility aspect was 89.77. The average score of all aspects of book eligibility is 90.23 in the range 86-100 and is in category 4 (very suitable)..
\end{abstract}

(C) 2021 Universitas Negeri Semarang

\begin{tabular}{lc}
\hline Alamat korespondensi: & P- ISSN 2252-6269 \\
Gedung B4 Lantai 1 FBS Unnes & E- ISSN 2721-4222 \\
Kampus Sekaran, Gunungpati, Semarang, 50229 &
\end{tabular}




\section{PENDAHULUAN}

Bahasa Arab di Indonesia merupakan salah satu bahasa yang dipelajari di lembagalembaga pendidikan formal maupun lembaga pendidikan non formal mulai dari jenjang SD/MI, SMP/MTs, SMA/MA, sampai jenjang perguruan tinggi.

Pembelajaran bahasa Arab memiliki tujuan utama yaitu untuk mengembangkan kemampuan siswa dalam menggunakan bahasa Arab baik itu secara lisan maupun tulis. Kemampuan menggunakan bahasa dalam pengajaran bahasa disebut keterampilan berbahasa. Dalam bahasa Arab terdapat empat keterampilan yang saling menunjang dalam kegiatan pembelajaran bahasa yaitu keterampilan menyimak, keterampilan berbicara, keterampilan membaca, dan keterampilan menulis. Setiap keterampilan tersebut saling berkaitan satu sama lain, sebab dalam memperoleh keterampilan berbahasa, biasanya ditempuh melalui hubungan urutan yang teratur dan merupakan satu kesatuan tunggal (Hermawan 2013:129).

Salah satu keterampilan bahasa yang sangat penting dimiliki oleh siswa adalah keterampilan menulis. Keterampilan menulis penting bagi dunia pendidikan karena dapat memudahkan dan membantu para pelajar untuk berpikir secara kreatif. Hal ini sesuai dengan tujuan pendidikan yang tertera dalam UU RI Nomor 20 Tahun 2003 bahwa pendidikan nasional bertujuan untuk mengembangkan potensi peserta didik agar menjadi manusia yang beriman dan bertakwa kepada Tuhan Yang Maha Esa, berakhlak mulia, sehat, berilmu, cakap, kreatif, madiri dan menjadi warga yang demokratis serta bertanggung jawab (Depdiknas :2003).

Sejalan dengan pernyataan tersebut, secara jelas pusat kurikulum telah memasukkan karakter "kreatif" sebagai potensi yang ingin dikembangkan pada masing-masing siswa. Untuk mengembangkan sikap kreatif ini dapat dilakukan melalui berbagai pembelajaran di kelas. Salah satunya dapat dilakukan melalui pembelajaran menulis. Karena pada pembelajaran menulis terjadi proses kreatif yang banyak melibatkan cara berpikir divergen (menyebar) daripada konvergen (memusat) (Dalman 2016:5).

Berdasarkan uraian sebelumnya, dapat disimpulkan bahwa kemampuan kreatif siswa dapat ditingkatkan melalui kegiatan pembelajaran menulis. Maka apabila kita mengacu pada simpulan tersebut sudah seharusnya setiap siswa mampu untuk menulis (menuangkan ide atau gagasan dalam sebuah tulisan). Namun berdasarkan hasil observasi peneliti pada pembelajaran keterampilan menulis pada jenjang MTs di kota Semarang, siswa justru tidak bisa menulis.

Berdasarkan wawancara dan observasi dengan beberapa guru dan siswa kelas VIII MTs di kota Semarang menyatakan bahwa kemampuan siswa masih kurang terutama dalam menulis bebas. Selama ini siswa masih kesulitan menyusun kata-kata menjadi sebuah kalimat ataupun paragraf. Kurangnya penguasaan kosakata dan tata bahasa menjadi kendala siswa dalam menulis, selain itu tidak adanya ide juga menyebabkan siswa kurang berminat untuk mulai menulis bebas.

Kesulitan yang dialami siswa dalam pembelajaran keterampilan menulis bahasa Arab dapat disebabkan oleh beberapa hal. Kendala tersebut dapat berasal dari apa saja yang melekat pada pembelajaran keterampilan menulis itu sendiri, seperti metode pengajaran guru, media pembelajaran, evaluasi pembelajaran hingga bahan ajar (Fauziyah 2017:5). Berdasarkan beberapa kendala yang disebutkan sebelumnya, penggunaan satu buku teks pelajaran dalam pembelajaran bahasa Arab dinilai sebagai pokok penyebab kesulitan belajar siswa dalam pembelajaran menulis.

Pada proses pembelajaran sebagian besar guru biasanya hanya menggunakan satu buku teks pelajaran (buku ajar) sebagai satu-satunya sumber acuan belajar siswa (Kurniawati 2012:14). Hal ini pula yang dilakukan oleh sebagian guru pengampu mata pelajaran bahasa Arab. Padahal, seperti dinyatakan Sitepu (2008:98), penyusunan buku teks sebagai sumber belajar di Indonesia dewasa ini terkesan kaku atau terikat pada materi pokok dalam kurikulum 
dan kurang mengembangkan kemampuan berpikir kreatif siswa. Dengan demikian, perlu adanya pengembangan sebuah buku nonteks pelajaran (buku penunjang) guna memperkuat dan melengkapi materi keterampilan menulis bahasa Arab pada buku teks pelajaran.

Buku penunjang yang akan peneliti kembangkan adalah buku penunjang bahasa Arab berbasis strategi RAFT (Role Audience Format Topic), yakni buku penunjang yang disusun dengan mengintegrasikan strategi $R A F T$ tersebut dalam pembelajaran keterampilan menulis bahasa Arab.

Strategi RAFT(Role Audience Format Topic) merupakan strategi yang dikembangkan oleh Corel Santa pada tahun 1988. Strategi ini digunakan untuk meningkatkan kemampuan menulis siswa (Ruddel 2005:288). Strategi RAFT terdiri dari empat unsur yaitu role (peran yang diambil oleh siswa), audience (objek dari tulisan yang hendak ditulis), format (bentuk tulisan), dan topic (topik atau bahasan yang dipilih dalam tulisan). Unsur-unsur tersebut dianggap jelas, logis dan sistematis. Logis berarti sesuai dengan logika atau penalaran. Sistematis dapat terlihat dari urutan langkah-langkahnya, yaitu berurutan dan teratur. Berdasarkan uraian tersebut, strategi RAFT (Role Audience Format Topic) dipilih sebagai dasar pengembangan buku penunjang keterampilan menulis bahasa Arab untuk siswa kelas VIII MTs.

\section{LANDASAN TEORI}

\section{Pengertian Buku}

Pengertian buku dalam Paperback Oxford English Dictionary (2012:75) adalah "a written or printed work consisting of pages fastened together along one side and bound in covers" yang artinya karya dalam bentuk tulisan atau hasil cetakan terdiri atas beberapa yang terikat bersama sepanjang satu sisi dan dijilid dalam sampul. Adapun buku menurut Kamus Besar Bahasa Indonesia ialah lembar kertas yang berjilid, berisi tulisan atau kosong (KBBI 2014:218).

Puskurbuk (2008:1) mengklasifikasikan buku pendidikan berdasarkan ruang lingkup kewenangan dalam pengendalian kualitasnya menjadi dua ragam, yakni buku teks pelajaran dan buku nonteks pelajaran.

Secara leksikal, buku teks pelajaran merupakan buku yang dipakai untuk mempelajari atau mendalami suatu subjek pengetahuan dan ilmu teknologi, sehingga mengandung penyajian asas-asas tentang subjek tersebut, termasuk karya kepanditan (scholary, literary) terkait subjek yang bersangkutan. Sedangkan buku nonteks pelajaran merupakan buku-buku yang tidak digunakan secara langsung sebagai buku untuk mempelajari satu bidang studi pada lembaga pendidikan. Pengendalian mutu buku teks pelaajaran merupakan kewenangan Badan Standar Nasional Pendidikan (BSNP), sedangkan mutu buku nonteks pelajaran merupakan kewenangan Pusat Perbukuan dan Kurikulum Departemen Pendidikan Nasional (Puskurbuk 2008:3).

Peraturan Menteri Pendidikan Nasional Nomor 2 tahun 2008 pasal 6 (2) menyatakan bahwa "Selain buku teks pelajaran, pendidikan dapat menggunakan buku panduan pendidikan, buku pengayaan, dan buku referensi dalam proses pembelajaran". Jadi buku nonteks terdiri dari buku pengayaan, buku referensi dan buku panduan pendidikan.

Buku pengayaan merupakan jenis buku berisi informasi yang melegkapi buku pelajaran pokok. Pengayaan yang dimaksud adalah memberikan informasi tentang pokok bahasan tertentu yang ada dalam kurikulum secara lebih luas dan/lebih dalam. Buku ini tidak disusun sepenuhnya berdasarkan kurikulum baik dari tujuan, materi pokok, dan metode penyajiannya. Buku ini tidak wajib digunakan siswa atau guru dalam proses pembelajaran, tetapi berguna bagi siswa yang mengalami kesulitan memahami pokok bahasan tertentu dalam buku pelajaran pokok (Sitepu 2012 : 16).

Beberapa uraian di atas menunjukkan bahwa buku teks pelajaran berbeda dengan buku nonteks pelajaran, baik dari segi prinsip pengembangan maupun struktur penyajiannya. Adapun penelitian ini akan membahas lebih lanjut mengenai buku nonteks pelajaran khususnya buku pengayaan. 
Buku pengayaan sering dikenal dengan buku bacaan yang digunakan sebagai bahan untuk menambah wawasan, pengalaman, dan pengetahuan pembacanya (Puskurbuk 2008:8). Terdapat tiga jenis buku pengayaan, yakni: buku pengayaan kepribadian, buku pengayaan keterampilan, dan buku pengayaan pengetahuan (Suherli 2008). Buku pengayaan kepribadian adalah buku yang memuat materi pengembangan kepribadian atau pengalaman batin. Buku pengayaan keterampilan adalah buku yang memuat materi yang dapat memperkaya dan meningkatkan kemampuan dasar para pembaca dalam rangka meningkatkan aktivitas praktis dan mandiri. Sedangkan buku pengayaan pengetahuan adalah buku yang memuat materi yang dapat memperkaya aspek kognitif pembaca (Puskurbuk 2008:8-15).

\section{Keterampilan Menulis Bahasa Arab}

Terdapat empat keterampilan yang saling menunjang dalam kegiatan pembelajaran bahasa Arab yaitu keterampilan menyimak, keterampilan berbicara, keterampilan membaca, dan keterampilan menulis (Hermawan 2013:129). Di antara beberapa keterampilan berbahasa, keterampilan menulis adalah keterampilan tertinggi dari empat keterampilan bebahasa. Menulis merupakan salah satu sarana berkomunikasi dengan bahasa antara orang dengan orang lainnya yang tidak terbatas oleh tempat dan waktu (Hamid 2016:104).

$$
\text { Adapun Hermawan (2013:51) }
$$

menyatakan bahwa keterampilan menulis (kitabah) adalah kemampuan dalam mendeskripsikan atau mengungkapkan isi pikiran, mulai aspek yang kompleks yaitu mengarang. Menulis (kitabah) berarti membuat lambang-lambang grafis yang menggambarkan suatu bahasa yang difahami seseorang untuk orang lain. Lambang-lambang grafis adalah kesatuan fonem.

Tujuan menulis (kitabah) menurut Muradi (2015:86) adalah (1) siswa mampu menulis dengan baik sesuai dengan tanda baca, struktur kalimat (tata bahasa), aspek morfologis dan sistaksis (sharf dan nahwu), (2) siswa mampu mengungkapkan pemikiran, perasaan, dan syair dalam bentuk tulisan dengan makna yang sempurna lagi indah, (3) siswa terbiasa berpikir runtut, sistematis, jelas, benar dan mampu diungkapkan dalam bentuk tulisan.

Kompetensi menulis (kitabah) secara umum dapat dikelompokkan menjadi dua, yaitu menulis terbimbing (muwajjah) dan menulis bebas (hurr). Menulis terbimbing merupakan kompetensi menulis dengan menggunakan panduan tertentu atau stimulus, misalnya berupa gambar, pertanyaan, dan kosakata atau kalimat pemandu. Adapun menulis bebas merupakan kompetensi menulis tanpa panduan atau stimulus, sehingga penulis bebas berkreasi dalam mengembangkan tulisannya (Asrori 2017:136).

\section{Strategi RAFT (Role Audience Format Topic)}

Strategi RAFT (Role Audince Format Topic) merupakan strategi yang dikembangkan oleh Carol Santa pada tahun 1988 (Ruddell 2005:288). Strategi ini digunakan untuk meningkatkan kemampuan menulis siswa dengan proses personalisasi tugas dan mengubah persepsi siswa menjadi dua hal, yaitu menulis topik dan menulis peristiwa atau kejadian. Adapun kata RAFT merupakan akronim dari $\mathrm{R}$ Role of the writer (Who are you?); A - Audience for the writer (To whom are you writing?); $\mathrm{F}$ - Format of the writing (What form will you writing take?); $\mathrm{T}$ Topic of the writing (What are you writing about?).

Role of the writer dapat diartikan sebagai sudut pandang (peran penulis). Jadi, penulis akan memilih sudut pandang dan memposisikan diri sebagai siapa di dalam tulisannya. Audience for the writer dapat diartikansebagai objek sasaran tulisan, yaitu pembaca seperti apa yang akan membaca tulisan tersebut atau ditujukan untuk siapa tulisan tersebut. Format of the writing berarti format yang akan digunakan dalam menulis atau bagaimana pola tulisan yang akan penulis pilih. Topic of the writing dapat diartikan sebagai topik yang akan penulis kembangkan dalam tulisan. Dapat disimpulkan bahwa strategi RAFT mendesain agar siswa dapat memposisikan diri sebagai siapa, untuk siapa, dalam format apa, dan topik spesifik apa sebagai bahan untuk menulis. Hal ini bertujuan supaya siswa lebih fokus terhadap tulisan yang akan ditulis. 
Shearer (dalam Ruddell 2005:289) mengemukakan bahwa setelah strategi $R A F T$ digunakan oleh banyak siswa dalam beberapa tingkatan, mereka menyukai ide yang diterapkan dalam strategi RAFT. Shearer kemudian membagi strategi $R A F T$ menjadi beberapa langkah sehingga siswa menjadi sukses dalam menulis. Shearer menjabarkan strategi RAFT menjadi lima langkah sebagai berikut:

\section{a) Langkah 1: Selecting the Topic (Menyeleksi Topic)}

Pada langkah awal siswa diperintahkan untuk menyeleksi topik apa yang akan mereka tulis. Dalam menyeleksi topik, topik yang dipilih dapat dikaitkan dengan materi yang sedang dipelajari siswa, dapat pula kejadian atau peristiwa yang terjadi pada lingkungan siswa.

\section{b) Langkah 2: Assumming a Role (Mengumpamakan sebuah Peran)}

Mengumpamakan sebuah peran, artinya siswa menentukan diri sebagai orang yang mengalami atau terlibat dalam peristiwa yang akan diceritakan. Dengan kata lain siswa memperkirakan tokoh yang mungkin ada dalam peristiwa atau kejadian tersebut. Pemilihan peran disesuaikan dengan topik yang telah dipilih pada langkah sebelumnya. Peran ini tentunya harus berhubungan atau memiliki keterkaitan dengan topik yang diangkat.

Dalam tahap ini, siswa dapat dibantu dengan membuat beberapa pertanyaan yang dapat membantu siswa dalam mendalami sebuah peran tersebut. Beberapa contoh pertanyaan yang dapat mendukung siswa dalam menentukan sebuah peran sebagai berikut

a. Apa yang saya ketahui tentang peran ini?

b. Agar dapat mengumpamakan peran ini, apa yang harus saya ketahui?

c. Sumber informasi apa saja yang dapat saya eksplor/jelajahi agar menjadi sebuah tulisan yang baik dari sudut pandang ini?

\footnotetext{
c) Langkah 3: Selecting an Audience (Menentukan Pembaca)
}

Pada langkah menentukan pembaca mengkuti pola yang sama seperti menyeleksi sebuah peran. Pembaca atau objek yang dipilih disesuaikan dengan topik dan peran yang telah ditentukan pada langkah sebelumnya. Kemudian pertanyaan yang dibuat sama dengan pertanyaan yang terdapat pada langkah mengumpamakan sebuah peran, hanya berbeda pada subjeknya saja, yaitu dibedakan antara peran dan pembaca.

\section{d) Langkah 4: Selecting a Format (Memilih sebuah Pola/Format) \\ Langkah keempat adalah memilih format} tulisan. Siswa menentukan format atau jenis tulisan yang mereka tulis. Ketika memilih sebuah format, siswa harus mengetahui jenis-jenis format tulisan yang akan digunakan.

e) Langkah 5: Organizing Information and Writing (Mengorganisasi Informasi dan Tulisan)

Pada langkah ini siswa diarahkan untuk mengumpulkan dan mengorganisasi informasi yang telah didapat dari langkah-langkah sebelumnya, mulai dari menentukan topik, peran, pembaca dan format penulisan. Setelah itu siswa dapat mengembangkan tulisan sesuai dengan sumber-sumber informasi yang telah mereka tentukan.

\section{Konsep Buku Penunjang Keterampilan Menulis Bahasa Arab Berbasis Strategi RAFT (Role Audience Format Topic)}

Rancangan buku penunjang keterampilan menulis bahasa Arab berbasis strategi RAFT (Role Audience Format Topic) untuk siswa MTs kelas VIII meliputi bentuk buku dan desain isi. Rancangan buku penunjang keterampilan menulis berbasis strategi RAFT (Role Audience Format Topic) untuk siswa MTs kelas VIII ini akan disusun dalam bentuk yang praktis dan mudah dibawa. Buku disertai dengan tampilan gambar dan komposisi warna yang variatif.

Adapun desain isi buku terdiri atas tiga bagian yaitu : bagian awal, bagian isi, dan bagian penutup. 
a) Bagian awal

Pada bagian awal terdapat halaman judul utama (sampul depan), halaman judul dalam, kata pengantar , petunjuk penggunaan, KI\&KD, serta halaman daftar isi.

\section{b) Bagian Isi}

Pada bagian isi bab terdapat halaman judul bab dan isi bab. Bagian halaman judul bab memuat judul bab, ilustrasi gambar dan kata pengantar atau appersepsi menuju tema. Bagian isi bab berisi sajian kosakata baru, penyajian pedoman gramatika, penyajian contoh menulis bebas berbasis strategi RAFT (Role Audience Format Topic), latihan menulis bebas berbasis strategi RAFT (Role Audience Format Topic), dan evaluasi.

\section{c) Bagian Akhir}

Bagian akhir buku penunjang keterampilan menulis bahasa Arab berbasis strategi RAFT (Role Audience Format Topic) berisi daftar pustaka dan biografi penulis.

Buku penunjang keterampilan menulis bahasa Arab berbasis strategi RAFT (Role Audience Format Topic) untuk siswa kelas VIII MTs yang peneliti kembangkan ini diharapkan dapat mendukung pembelajaran keterampilan menulis bahasa Arab dan menjadi pendamping belajar siswa.

\section{METODE PENELITIAN}

Penelitian ini termasuk dalam jenis penelitian kualitatif dan kuantitatif dengan desain penelitian dan pengembangan (Research \& Develoment) selanjutnya akan disingkat dengan R\&D. Menurut Sugiyono (2018:297) R\&D adalah penelitian yang digunakan untuk menghasilkan produk tertentu, dan menguji keefektifan produk tersebut. Penelitian dan pengembangan atau Research and Development (R\&D) adalah suatu proses atau langkah-langkah untuk mengembangkan suatu produk baru atau menyempurnakan produk yang telah ada, yang dapat dipertanggungjawabkan.

Sugiyono (2014:408) menyatakan terdapat sepuluh tahapan kegiatan penelitian dan pengembangan, yaitu : (1) merumuskan potensi dan masalah; (2) mengumpulkan informasi; (3) mendesain produk; (4) memvalidasi desain produk kepada ahli; (5) melakukan perbaikan desain produk ; (6) melakukan uji coba produk; (7) merevisi produk; (8) melakukan uji coba pemakaian dalam lingkup yang lebih luas; (9) merevisi produk lagi, dan (10) melakukan pembuatan produk secara massal.

Pada penelitian ini peneliti menggunakan model pengembangan yang dikemukakan oleh Sugiyono tersebut, Akan tetapi, dalam mengembangkan buku penunjang keterampilan menulis berbasis RAFT (Role Audience Fomat Topic) ini, langkah-langkah penelitian pengembangan tersebut direduksi hanya sampai tahap kelima (Revisi Desain) tanpa bermaksud mengurangi kualitas penelitian Research and Development. Peneliti hanya menerapkan lima tahapan penelitian karena waktu dan biaya yang dibutuhkan memungkinkan peneliti untuk menerapkan sepuluh tahapan penelitian.

Adapun tahapan-tahapan penelitian pengembangan yang hendak dilakukan peneliti yaitu, (1) merumuskan potensi dan masalah, (2) pengumpulan data, untuk mengembangkan purwarupa buku penunjang keterampilan menulis bahasa Arab berbasis RAFT (Role Audince Format Topic); (3) desain produk, yakni kegiatan penyusunan purwarupa buku penunjang keterampilan menulis bahasa Arab berbasis RAFT (Role Audince Format Topic) berdasarkan hasil analisis kebutuhan ; (4) validasi desain, yaitu penilaian purwarupa oleh ahli dan guru yang sudah berpengalaman; (5) revisi desain, yaitu melakukan koreksi dan perbaikan terhadap buku penunjang keterampilan menulis bahasa Arab berbasis strategi RAFT (Role Audience Format Topic) sesuai dengan masukan dari para ahli dan guru.

Adapun langkah-langkah penelitian yang dilakukan dalam penelitian ini ditunjukkan pada gambar berikut ini.

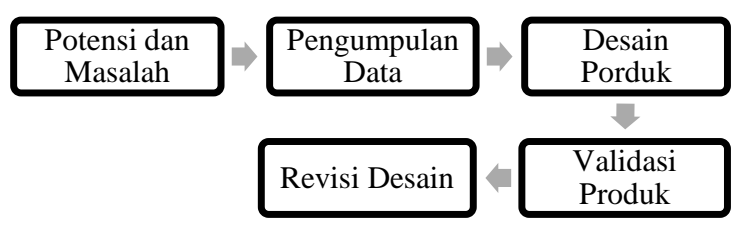


Gambar 1 Tahapan Penelitian

Data pada penelitian ini diperoleh melalui non tes. Instrumen data non tes yang digunakan berupa wawancara, observasi dan angket kebutuhan guru dan siswa, angket uji validasi ahli terhadap buku penunjang keterampilan menulis bahasa Arab berbasis strategi RAFT (Role Audience Format Topic).

\section{HASIL PENELITIAN DAN PEMBAHASAN}

Hasil penelitian dan pembahasan pada bab ini meliputi tiga hal, yaitu: (1) hasil analisis kebutuhan guru dan siswa terhadap pengembangan buku penunjang keterampilan menulis bahasa Arab berbasis strategi RAFT (Role Audience Format Topic), (2) purwarupa buku penunjang keterampilan menulis bahasa Arab berbasis strategi RAFT (Role Audience Format Topic), dan (3) analisis validasi dan saran perbaikan ahli terhadap buku penunjang keterampilan menulis bahasa Arab berbasis strategi RAFT (Role Audience Format Topic).

\section{Hasil Analisis Kebutuhan}

Berdasarkan hasil angket kebutuhan guru dan siswa terhadap buku penunjang keterampilan menulis bahasa Arab berbasis strategi RAFT (Role Audience Format Topic), dapat disimpulkan bahwa guru dan siswa setuju dengan dikembangkannya buku penunjang keterampilan menulis bahasa Arab berbasis strategi RAFT (Role Audience Format Topic). Dengan adanya buku penunjang tersebut diharapkan dapat memotivasi siswa untuk belajar menulis, dan meningkatkan kemampuan siswa dalam menulis bahasa Arab.

Hasil analisis kebutuhan guru dan siswa yang peneliti peroleh di antaranya, yaitu (1) terdapat 10-15 kosakata pada awal materi, (2) terdapat ilustrasi sesuai kebutuhan pada buku, (3) terdapat harakat pada materi, (4) penjelasan tata bahasa diuraikan secara ringkas namun mudah dipahami pembaca, (5) terdapat evaluasi, (6) jenis evaluasi campuran, (7) terdapat petunjuk penggunaan buku, (8) bahasa yang digunakan bahasa Arab dan Indonesia, (9) ukuran buku B5 (buku tulis), (10) jenis font Arab menggunakan Sakkal Majalla ukuran 18, (11) jenis font Indonesia menggunakan Times New Roman ukuran 12, (12) warna sampul buku berupa warna tersier (campuran), (13) isi buku berwarna sesuai kebutuhan, (14) jenis kertas yang digunakan Ivory, (15) jenis penjilidan spiral.

\section{Purwarupa Buku Penunjang Keterampilan Menulis Bahasa Arab Berbasis Strategi RAFT (Role Audience Format Topic)}

Desain purwarupa buku penunjang keterampilan menulis bahasa Arab berbasis strategi RAFT (Role Audience Format Topic) terdiri dari tiga bagian yaitu: bagian awal, bagian isi, dan bagian penutup. Pada bagian awal terdapat halaman judul utama (sampul depan), halaman judul dalam, halaman kata pengantar, petunjuk penggunaan, halaman KI\&KD, serta halaman daftar isi.

Pada bagian isi buku terdapat judul bab, materi buku penunjang penunjang keterampilan menulis bahasa Arab berbasis strategi RAFT (Role Audience Format Topic), dan kata-kata mutiara. Adapun pada bagian akhir buku berisi daftar pustaka dan biografi penulis.

Berikut gambar purwarupa buku penunjang keterampilan menulis bahasa Arab berbasis strategi RAFT (Role Audience Format Topic).

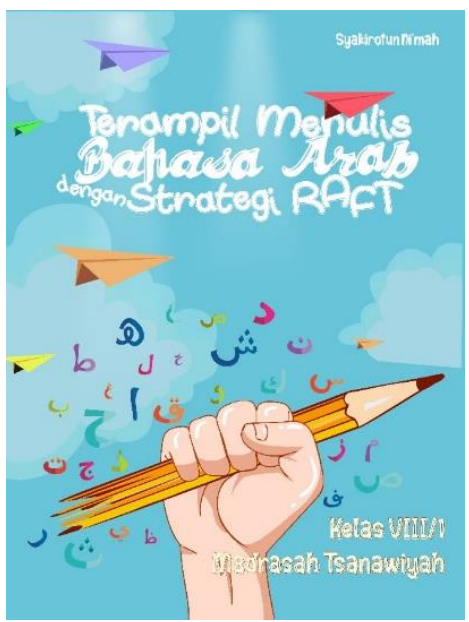

Gambar 2 Desain Sampul Depan 


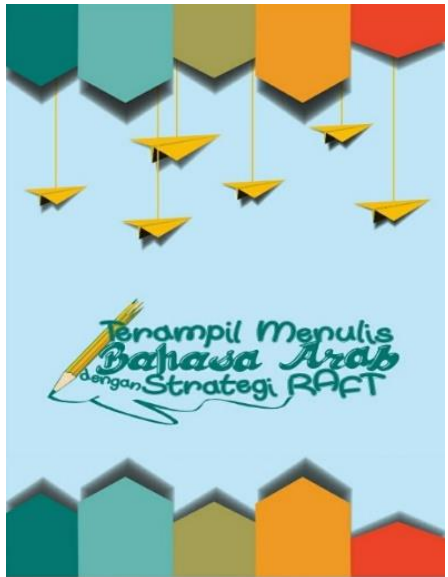

Gambar 3 Desain Sampul Dalam

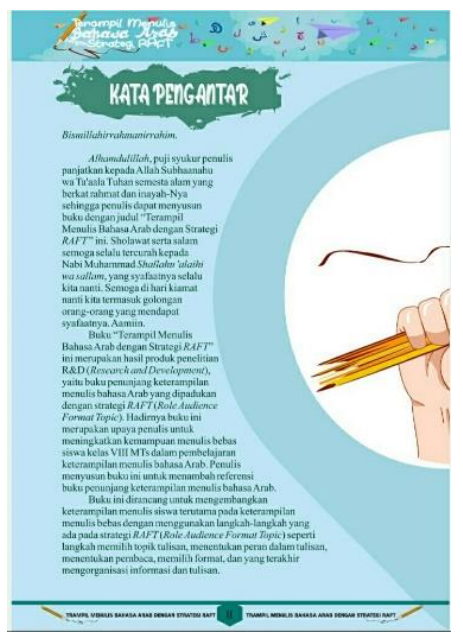

Gambar 3 Desain Halaman Pengantar

Halaman kata pengantar berisi ucapan terima kasih, penjelasan singkat tentang isi buku, serta permohonan kritik dan saran dari pembaca. Desain halaman kata pengantar divisualisasikan dengan ilustrasi yang sama pada sampul depan buku yaitu sebuah tangan yang menggenggam pensil.

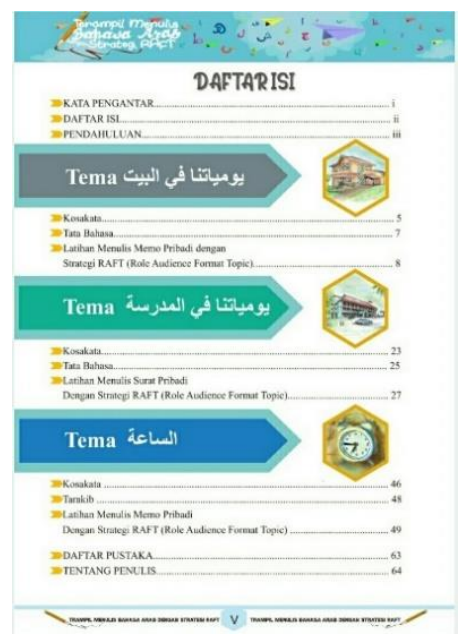

Gambar 4 Desain Daftar Isi

Halaman daftar isi terdiri dari judul bab dengan nomor halaman yang sesuai dengan halaman isi buku. Daftar isi berguna memudahkan pembaca untuk melihat nomor halaman materi yang akan dipelajari.

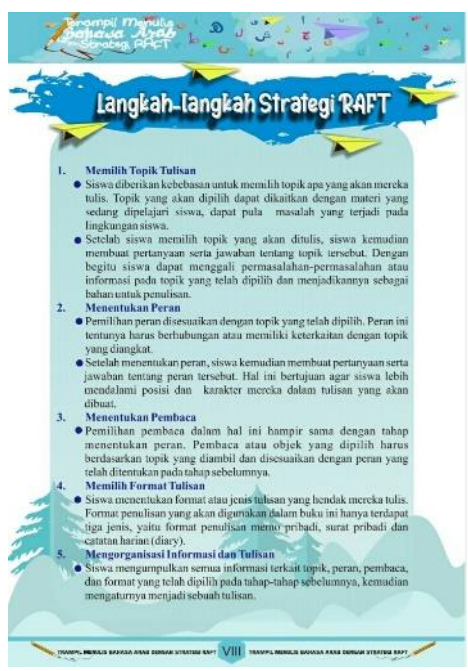

Gambar 5 Desain Petunjuk Penggunaan Buku

Halaman petunjuk penggunaan buku berisi penjelasan singkat tentang strategi $R A F T$ (Role Audience Format Topic) dan langkah-langkah menulis dengan strategi RAFT (Role Audience Format Topic). 


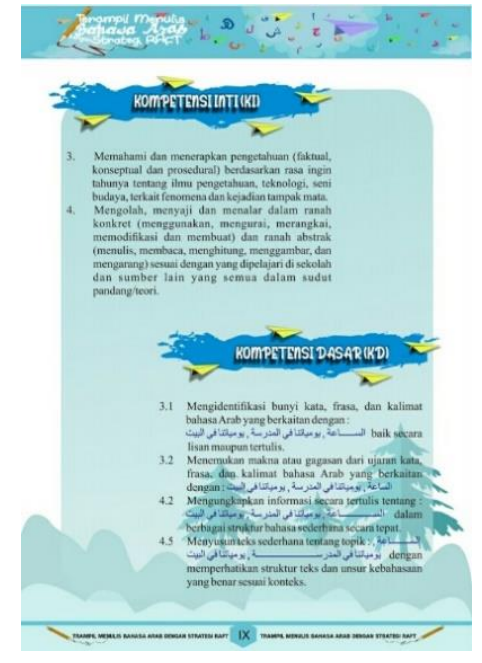

Gambar 6 Desain Halaman KI dan KD

Halaman KI dan KD berisi Kompetensi Inti dan Kompetensi Dasar siswa kelas VIII MTs. Halaman KI dan KD ini berguna untuk mempermudah pembaca mengetahui kompetensi-kompetensi yang hendak dicapai dalam buku ini.

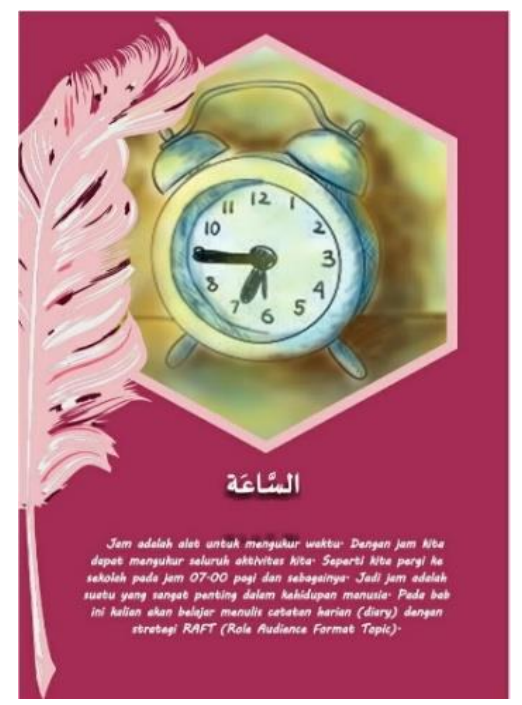

Gambar 7 Desain Sampul Judul Bab dan Appersepsi

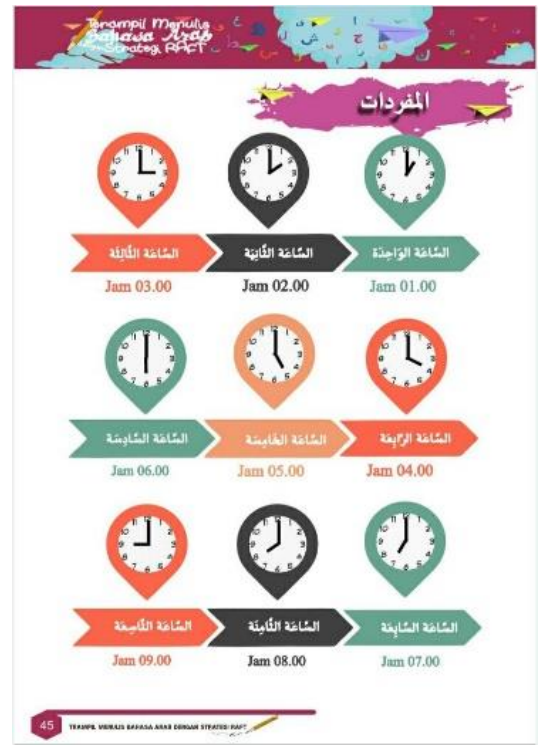

Gambar 8 Desain Kosakata (Mufrodat)

Berdasarkan kriteria jawaban pilihan responden pada angket kebutuhan dan pertimbangan peneliti untuk tiap tema minimal terdapat 10-15 kosakata. Kosakata tersebut disajikan dalam bentuk kalimat isim dan fi'il.

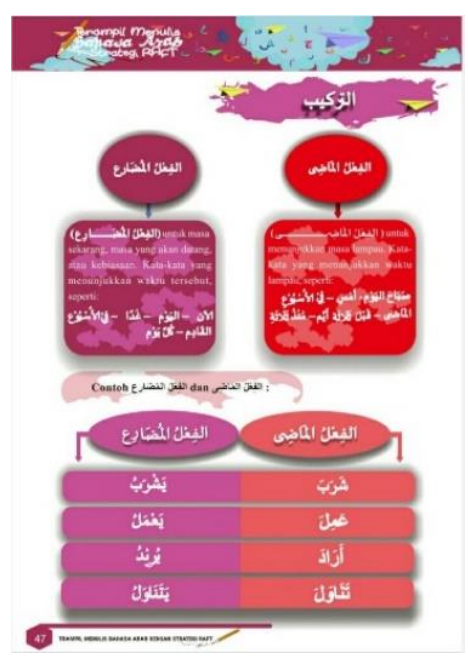

Gambar 9 Desain Tata Bahasa (Tarakib)

Berdasarkan kriteria jawaban pilihan responden pada angket kebutuhan, tata bahasa (tarakib) disajikan secara ringkas agar dapat dipahami pembaca. 


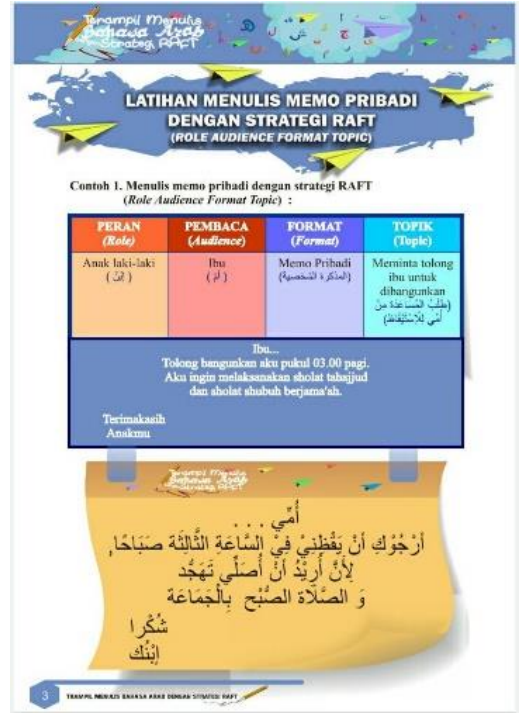

Gambar 10 Latihan Menulis dengan Strategi RAFT (Role Audience Format Topic)

Bentuk penyajian latihan menulis dengan strategi RAFT (Role Audience Format Topic) diawali dengan contoh menulis menggunakan strategi RAFT (Role Audience Format Topic), kemudian dilanjutkan dengan instruksi menulis sesuai dengan langkah-langkah strategi $R A F T$ (Role Audience Format Topic).

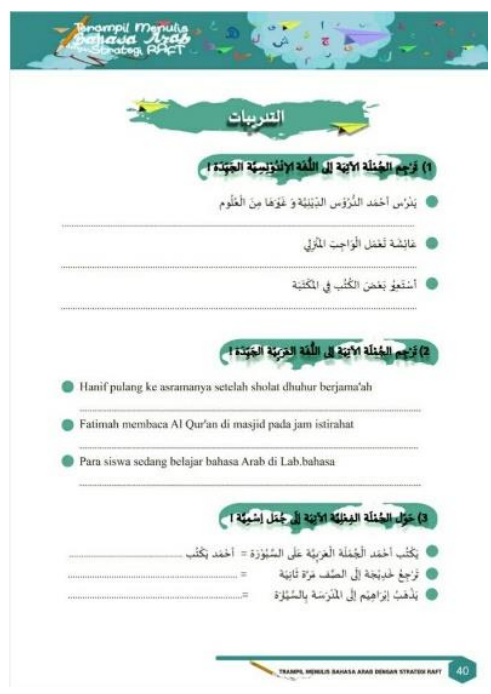

Gambar 11 Desain Evaluasi

Evaluasi yang disajikan berjumlah 1-5 soal. Jenis evaluasi yang disajikan bervariasi agar siswa tidak bosan dalam mengerjakan. Bentuk soal diantaranya yaitu latihan menerjemahkan kalimat ke dalam bahasa Arab dan bahasa Indonesia, menyusun kata menjadi kalimat dan membuat sebuah tulisan dengan strategi $R A F T$ (Role Audience Format Topic).

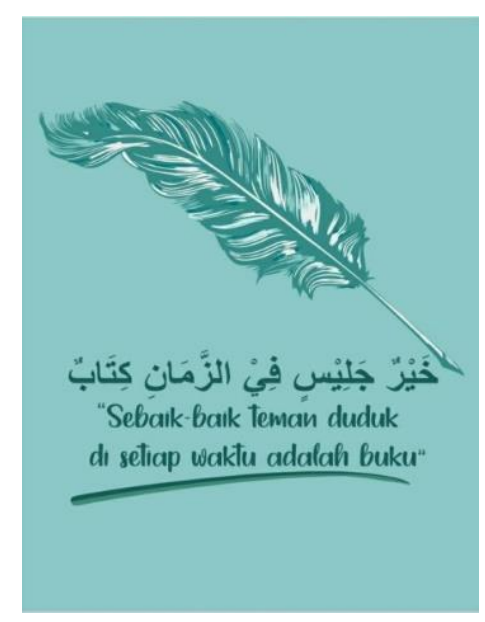

\section{Gambar 12 Desain Kata Mutiara}

Kata mutiara disajikan pada setiap akhir bab setelah evaluasi. Desain halaman kata mutiara divisualisasikan pada gambar di atas.

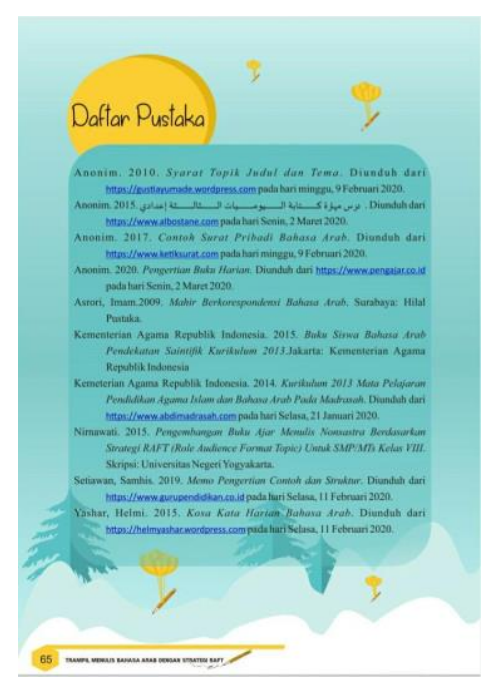

Gambar 13 Desain Daftar Pustaka

Daftar pustaka terdiri dari buku yang digunakan sebagai rujukan dalam penulisan buku penunjang keterampilan menulis bahasa Arab berbasis strategi RAFT (Role Audience Format Topic). Penulisan daftar pustaka di awali dengan nama pengarang (yang disusun alfabetis), 
tahun terbit, judul buku, tempat terbit dan nama penerbit.

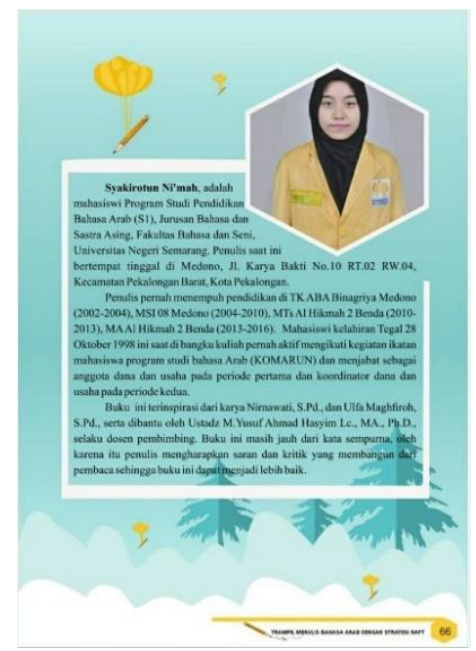

Gambar 14 Biografi Penulis

Halaman biografi penulis pada buku penunjang keterampilan menulis bahasa Arab berbasis strategi RAFT (Role Audience Format Topic) ditulis untuk melengkapi buku, sehingga pembaca dapat mengetahui identitas penulis. Adapun isi biografi penulis terdiri dari nama penulis, kelahiran penulis, riwayat pendidikan penulis dan pengalaman penulis.

\section{Validasi Ahli dan Guru}

Validasi ahlidan guru terhadap buku penunjang keterampilan menulis bahasa Arab berbasis strategi RAFT (Role Audience Format Topic) meliputi empat aspek, yaitu: (1) aspek kelayakan isi, (2) aspek kelayakan penyajian, (3) aspek kelayakan bahasa, dan (4) aspek kelayakan kegrafikan.

Tabel 1 Nilai Total Aspek Kelayakan Buku

\begin{tabular}{|c|c|c|c|}
\hline No. & \multicolumn{2}{|c|}{ Aspek Penilaian } & Nilai \\
\hline 1. & \multicolumn{2}{|c|}{ Aspek Kelayakan Isi } & 90,56 \\
\hline 2. & Aspek & Kelayakan & 90,95 \\
\hline & \multicolumn{3}{|l|}{ Penyajian } \\
\hline 3. & Aspek & Kelayakan & 89,66 \\
\hline & \multicolumn{3}{|l|}{ Bahasa } \\
\hline 4. & Aspek & Kelayakan & 89,77 \\
\hline & \multicolumn{3}{|c|}{ Kegrafikan } \\
\hline
\end{tabular}

Berdasarkan tabel 1 di atas dapat diketahui bahwa nilai dari keseluruhan aspek kelayakan buku adalah 90,23 maka nilai keseluruhan aspek kelayakan buku berada pada rentang nilai 86-100 dan termasuk dalam skala 4 dengan kategori sangat sesuai (sangat layak). Dengan demikian, dapat disimpulkan bahwa buku penunjang keterampilan menulis bahasa Arab berbasis startegi RAFT (Role Audience Format Topic) untuk siswa kelas VIII MTs yang peneliti kembangkan sangat layak untuk digunakan oleh siswa kelas VIII MTs guna meningkatkan pembelajaran bahasa Arab.

\section{Saran Perbaikan Terhadap Purwarupa Buku Penunjang Keterampilan Menulis Bahasa Arab Berbasis Strategi RAFT (Role Audience Format Topic)}

Saran perbaikan terhadap buku penunjang keterampilan menulis bahasa Arab berbasis strategi RAFT (Role Audience Format Topic), diantaranya (1) penambahan $\mathrm{KI}$ dan $\mathrm{KD}$, (2) perbaikan penyajian makna kosakata, (3) perbaikan penulisan harakat dan istilah pada materi, (4) perbaikan petunjuk soal evaluasi, dan (5) perbaikan jenis evaluasi.

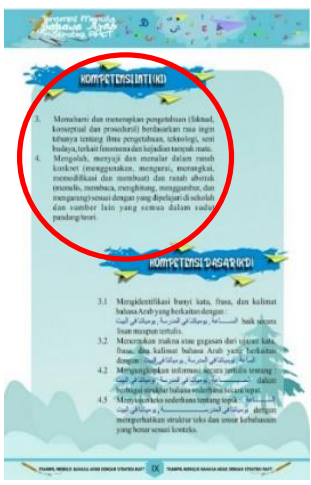

Sebelum

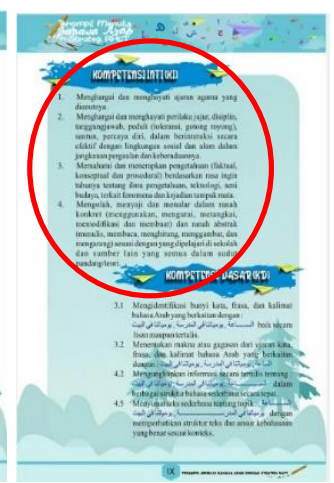

Sesudah
Gambar 15 Penambahan KI dan KD

Sebelum diperbaiki KI (Kompetensi Inti) dan KD (Kompetensi Dasar) yang disajikan dalam buku hanya bagian nomor tiga dan empat. Penambahan KI KD nomor satu dan dua 
dilakukan karena KI-1 yang merupakan KI spiritual dan KI-2 yang merupakan sikap sosial adalah kompetensi-kompetensi yang wajib dicapai dalam kurikulum.

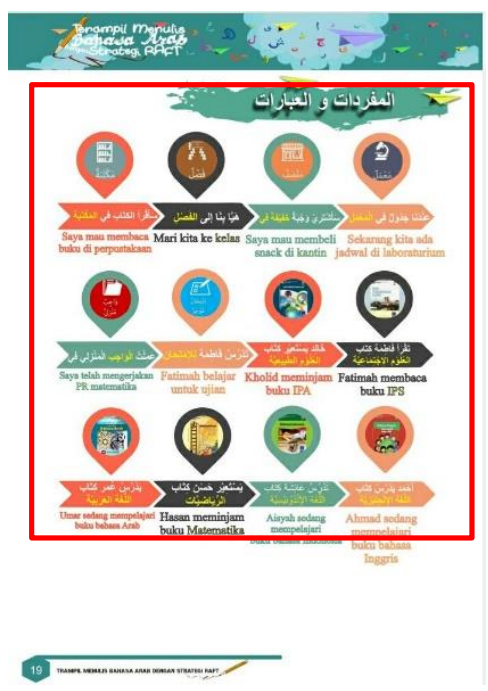

Gambar 16 Sebelum Perbaikan Penyajian Kosakata

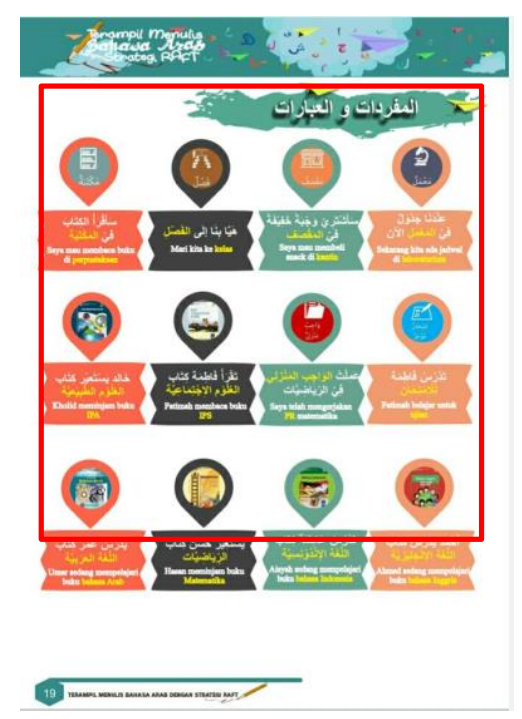

Gambar 17 Sesudah Perbaikan Penyajian Kosakata

Gambar 16 dan 17 di atas adalah penyajian kosakata sebelum dan sesudah dilakukan perbaikan. Sesuai saran perbaikan dari ahli materi bahwa makna kosakata dan kosakata bahasa Arab disatukan dalam satu bentuk gambar. Dengan begitu diharapkan siswa tidak salah dalam memahami makna kosakata.
Adapun perbaikan penulisan harakat dan istilah bahasa Arab dari ahli materi adalah sebagai berikut.

Tabel 2 Perbaikan Penulisan Harakat dan Istilah pada Materi

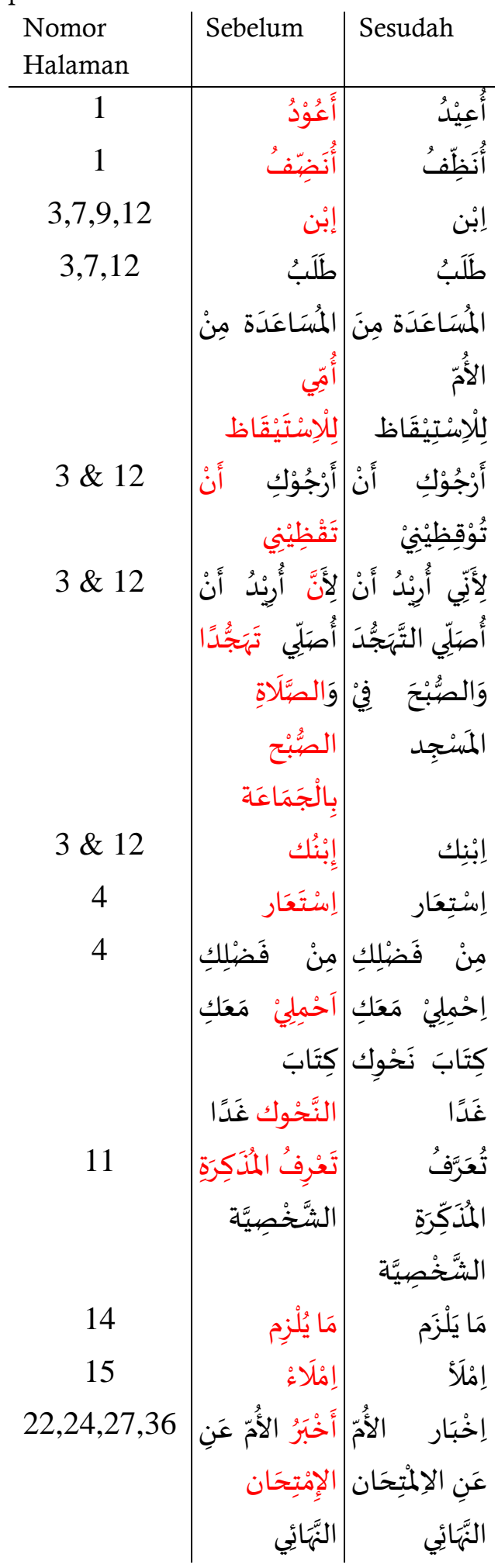




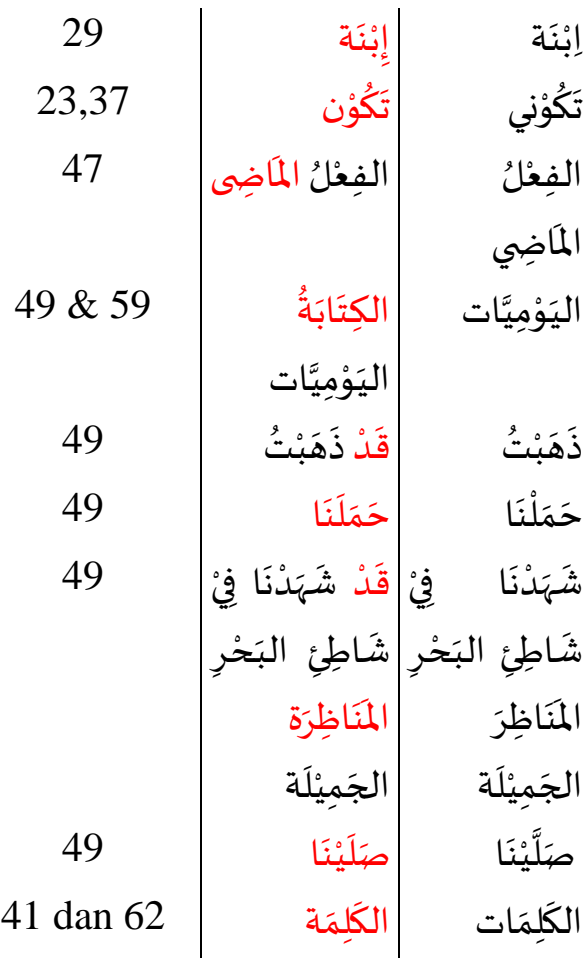

Kemudian sesuai saran dan masukan dari ahli materi mengenai petunjuk soal evaluasi pada buku penunjang keterampilan menulis bahasa Arab berbasis strategi RAFT (Role Audience Format Topic) adalah untuk mengubah kalimat petunjuk soal evaluasi. Perbaikan petunjuk soal pada bagian evaluasi dilakukan karena terdapat beberapa petunjuk soal yang belum spesifik maksudnya. Perbaikan petunjuk soal dilakukan agar siswa dapat menjawab sesuai dengan maksud soal tersebut.

Tabel 3 perbaikan petunjuk soal pada bagian evaluasi

\begin{tabular}{|c|c|c|}
\hline $\begin{array}{l}\text { Nomor } \\
\text { Halaman }\end{array}$ & Sebelum & Sesudah \\
\hline 41 & 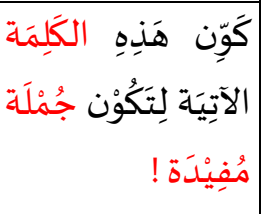 & 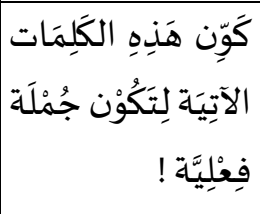 \\
\hline 62 & 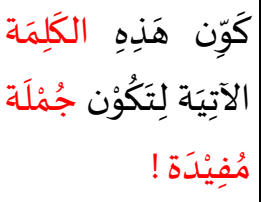 & 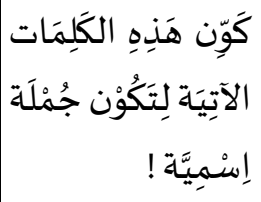 \\
\hline
\end{tabular}

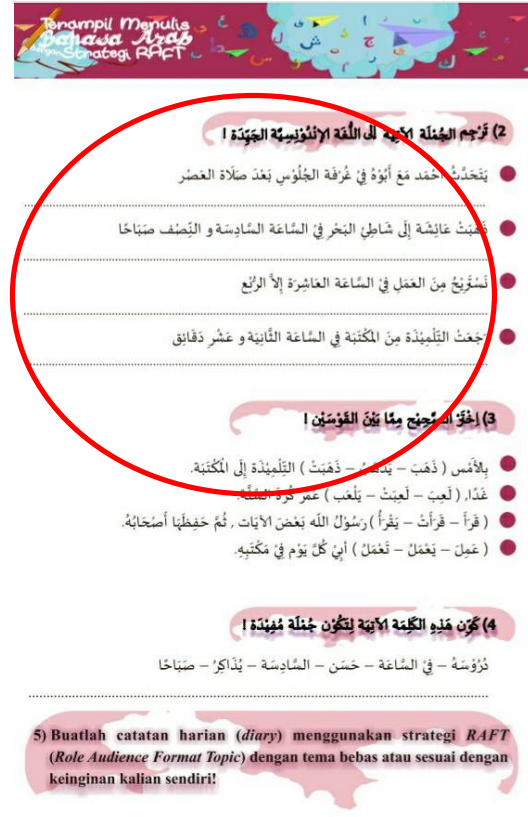

Gambar 18 Sebelum Perbaikan Jenis Soal Evaluasi

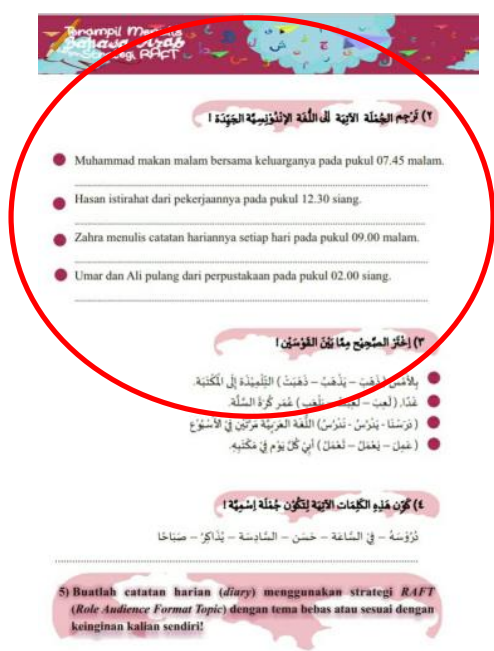

Gambar 19 Sesudah Perbaikan Jenis Soal Evaluasi

Pada bagian evaluasi pada awalnya terdapat soal untuk menerjemahkan kalimat dari bَرْجِم ( namun berdasarkan saran perbaikan dari para ahli bahwa latihan soal yang tepat untuk melatih keterampilan menulis bahasa Arab siswa adalah dengan soal menerjemahkan kalimat dari bahasa 
Indonesia kedalam bahasa Arab( تَرْجم (الجُمْلَة الآتِيَّة إلى اللُّنَة العَرَبِيَّة الجَيَّدَة

\section{PENUTUP}

Berdasarkan hasil dari penelitian ini adalah analisis gambaran buku penunjang yang digunakan guru di sekolah masih sangat minim, guru jarang sekali menggunakan buku tambahan dalam pembelajaran keterampilan menulis bahasa Arab. kebutuhan guru mata pelajaran bahasa Arab dan siswa terhadap buku penunjang keterampilan menulis bahasa Arab berbasis strategi RAFT (Role Audience Format Topic) menunjukkan dari 3 guru dan 50 siswa bahwa 2 guru $(66,7 \%)$ dan 37 siswa (74\%) menyampaikan pengembangan buku penunjang keterampilan menulis bahasa Arab berbasis strategi RAFT (Role Audience Format Topic) dibutuhkan.

Purwarupa buku penunjang dikategorikan menjadi tiga bagian meliputi pertama, bagian awal buku terdiri dari halaman judul utama (sampul depan), halaman judul dalam, halaman kata pengantar, petunjuk penggunaan buku, halaman KI \& KD, serta halaman daftar isi. Kedua, bagian isi buku terdiri dari halaman judul bab, materi buku penunjang penunjang keterampilan menulis bahasa Arab berbasis strategi RAFT (Role Audience Format Topic), dan kata mutiara. Ketiga, bagian akhir buku berisi daftar pustaka dan biografi penulis.

Analisis penilaian ahli terhadap purwarupa buku penunjang keterampilan menulis bahasa Arab berbasis strategi RAFT (Role Audience Format Topic) dapat disimpulkan bahwa buku tersebut dari aspek kelayakan isi, kelayakan penyajian, kelayakan bahasa dan kelayakan kegrafikan sudah sangat baik dengan nilai rata-rata 90,23 dan termasuk kategori 4 (sangat sesuai/sangat layak). Adapun saran dan perbaikan dari para ahli meliputi, diantaranya (1) penambahan KI dan $\mathrm{KD}$, (2) perbaikan penyajian makna kosakata, (3) perbaikan penulisan harakat dan istilah pada materi, (4) perbaikan petunjuk soal evaluasi, dan (5) perbaikan jenis evaluasi.

\section{DAFTAR PUSTAKA}

Asrori, Imam M.T., M. Ainin. 2017. Evaluasi Pembelajaran Bahasa Arab. Malang: Misykat.

Dalman. 2016. Keterampilan Menulis. Jakarta: PT Raja Grafindo Persada

Depdiknas. 2003. Pedoman Penilaian Buku Nonteks Pelajaran. Jakarta: Departemen Pendidikan Nasional

Fauziyah, Nur Laili. 2017. Pengembangan Buku Pengayaan Berbasis Pendekatan 4P (Person, Press, Process, dan Product) Untuk Keterampilan Menulis Bahasa Arab Siswa Kelas XI MA/SMA. Skripsi: Universitas Negeri Semarang.

Hamidi. 2000. Metode penelitian kualitatif. Malang: UMM Press

Hermawan, Acep. 2013. Metodologi Pembelajaran Bahasa Arab. Bandung: PT. Remaja Rosdakarya Offset.

Kurniawati, Veronika Hevi. 2012. Perilaku Pemanfaatan Media Internet Sebagai Sumber Belajar. Jurnal Sosialitas (2) 1-10

Muradi, Ahmad. 2015. Pembelajaran Menulis Bahasa Arab Dalam Perspektif Komunikatif. Jakarta: Prenada Media Grup.

Peraturan Menteri Pendidikan Nasional Republik Indonesia Nomor 2 Tahun 2008 tentang Buku. 2008. Jakarta: Departemen Pendidikan Nasional.

Puskurbuk. 2008. Pedoman Penulisan Buku Nonteks: Buku Pengayaan, Referensi, Dan Panduan Pensisik. Jakarta: Depdiknas.

Ruddell, Martha Rapp. 2005. Teaching Content Reading And Writing. United States of America: John Wiley \& Sons, Inc.

Sitepu, B.P. 2008. Buku Teks Pelajaran Berbasis Aneka Sumber. Jurnal pendidikan penabur. Vol.10

Sugiyono, 2018. Metode Penelitian Pendekatan Kuantitatif, Kualitatif dan $R \& D$. Bandung: Alfabeta

Sugiyono. 2014. Statistika Untuk Penelitian. Bandung: CV. Alfabeta 